\title{
Pengelolaan Sumber Daya Energi Berbasis Lingkungan dalam Rangka Mewujudkan Negara Kesejahteraan
}

\author{
I Gusti Ayu Ketut Rachmi Handayani, Edi As'Adi, dan Sartika Bani Kharisma \\ Fakultas Hukum Universitas Sebelas Maret \\ Jln. Ir. Sutami No. 36 A, Jebres, Surakarta, Kota Surakarta, Jawa Tengah \\ ayu_igk@yahoo.com; 454dilaw@gmail.com; tika.kharisma11@gmail.com
}

Naskah diterima: 4/11/2016; revisi: 29/11/2016; disetujui: 23/12/2016

\begin{abstract}
Today the energy resource management in realizing the prosperity concept as the aspiration of Indonesia people tends to threat the sustainability of living environment of Indonesian people that, in fact, also becomes the objective of state to protect all Indonesia people and all areas of Indonesia. Based on the explanation of this background, the problems in living environment-based energy resource management for Indonesia people arise. Those problems include first, the legal-politic in managing the energy resource today; second, inconsistency of legal politics in the energy resource management towards the sustainability of living environment and third, legal politics in managing the living environment-based energy resource in future. This is a normative research that concluded that first, normatively and sociologically, the management of the energy resource today tends to ignore any values of living environment-based local wisdoms. Second, capitalism and liberalism in energy resource management today tends to threat the sustainability of living environment of Indonesia people. Third, in future, there is a need for legal politics of the integral, comprehensive and continuous living environment based energy resource management.
\end{abstract}

Keywords : Resources; energy; legal politics; environment; prosperity ental

\section{Abstrak}

Dewasa ini pengelolaan sumber daya energi dalam mewujudkan konsep kemakmuran yang menjadi cita-cita bangsa Indonesia cenderung mengancam kelestarian lingkungan hidup bangsa Indonesia yang sejatinya juga menjadi tujuan negara untuk melindungi segenap bangsa Indonesia dan seluruh tumpah darah Indonesia. Bertolak dari uraian latar belakang tersebut muncul problematika pengelolaan sumber daya energi berbasis lingkungan hidup bagi rakyat Indonesia. Tiga pokok persoalan yang muncul adalah: pertama, politik hukum pengelolaan sumber daya energi saat ini. Kedua, inkonsistensi politik hukum pengelolaan sumber daya energi terhadap kelestarian lingkungan hidup. Ketiga, politik hukum pengelolaan sumber daya energi yang berbasis lingkungan hidup di masa depan. Jenis penelitian ini merupakan penelitian normatif. Hasil penelitian menyimpulkan: pertama, secara normatif dan sosiologis pengelolaan sumber daya energi saat ini cenderung mengabaikan nilai kearifan lokal yang berbasis lingkungan hidup. Kedua, kapitalisasi dan liberalisasi pengelolaan sumber daya energi saat ini cenderung mengancam kelestarian lingkungan hidup bangsa Indonesia. Ketiga, di masa depan perlu adanya politik hukum pengelolaan sumber daya energi berbasis lingkungan hidup secara terintegral, komprehensif dan berkesinambungan.

Kata-kata Kunci: Sumber daya; energi; politik hukum; lingkungan; kesejahteraan 


\section{Pendahuluan}

Sumber daya energi pada dasarnya sebagai kekayaan negara yang semestinya tetap dilindungi dan digunakan untuk sebesar-besarnya kemakmuran rakyat Indonesia. Secara normatif pemikiran tersebut di atas sesuai dengan landasan politik hukum dan demokrasi ekonomi Indonesia. Di dalam konstitusi Pasal 33 ayat (1), (2) dan (3) Undang-Undang Dasar Negara RI Tahun 1945 disebutkan bahwa: (1) Perekonomian disusun sebagai usaha bersama berdasar atas azas kekeluargaan; (2) Cabang-cabang produksi yang penting bagi negara dan menguasai hajat hidup orang banyak dikuasai oleh negara; (3) Bumi dan air dan kekayaan alam yang terkandung di dalamnya dikuasai oleh negara dan dipergunakan untuk sebesar-besarnya kemakmuran rakyat.

Bertolak dari konsep kemakmuran rakyat di atas, dapat dipahami bahwa pada dasarnya pengelolaan sumber daya energi memiliki esensi pokok untuk menunjang keberlangsungan hidup rakyat Indonesia dalam memenuhi kebutuhan hidupnya. Pemikiran demikian adalah wajar dan sesuai kodrat atau sifat dasar manusia sebagai makhluk ekonomi (hommo economicus) yang rasional (atau a rational maximize) selalu berkeinginan untuk memuaskan kepentingan pribadinya (his satisfactions-what we shall call his "self interest"). ${ }^{1}$

Namun demikian, seiring perkembangan jumlah kebutuhan energi yang cenderung semakin meningkat seperti sekarang ini, pengelolaan sumber daya energi dewasa ini cenderung mengabaikan kelestarian lingkungan hidup yang semestinya menjadi basis pengelolaan sumber daya energi secara berkesinambungan, komprehensif dan terintegral serta linier dengan kebutuhan manusia akan lingkungan yang baik dan sehat. ${ }^{2}$ Bila pengelolaan sumber daya energi hanya didasarkan kepada kebutuhan ekonomi masyarakat secara terusmenerus dan mengabaikan kelestarian lingkungan hidup niscaya dapat membahayakan keselamatan ekologi dan ekosistem lingkungan hidup negara Indonesia. Fakta menunjukkan bahwa kesalahan dalam pengelolaan sumber daya energi sangat berdampak luas terhadap kelestarian lingkungan hidup dan

\footnotetext{
${ }^{1}$ Richard A. Posner, Economic Analysis of Law, Fifth.ed.AspenPublishers, New York, 1998, hlm. 3-5.

${ }^{2}$ Baca selengkapnya dalam Pasal 28 H ayat (1) UUD NRI 1945.
} 
mengancam kehidupan masyarakat di sekitarnya. Kasus mal kelola sumber daya energi yang terjadi Maret 2006 di wilayah sungai Barantas Porong Sidoarjo Jawa Timur oleh PT. Lapindo menjadi bukti bahwa kelestarian lingkungan hidup lebih penting dibandingkan dengan kebutuhan energi.

Banjir lumpur panas Sidoarjo, juga dikenal dengan sebutan Lumpur Lapindo (Lula) atau Lumpur Sidoarjo (Lusi), adalah peristiwa menyemburnya lumpur panas di lokasi pengeboran Lapindo Brantas Inc. di Dusun Balongnongo Desa Renokenongo, Kecamatan Porong, Kabupaten Sidoarjo, Jawa Timur, Indonesia, sejak 29 Mei 2006. Semburan lumpur panas selama beberapa bulan ini menyebabkan tergenangnya kawasan permukiman, pertanian, dan perindustrian di tiga kecamatan di sekitarnya, serta memengaruhi aktivitas perekonomian di Jawa Timur, seperti terlihat dalam ragaan berikut ini: ${ }^{3}$

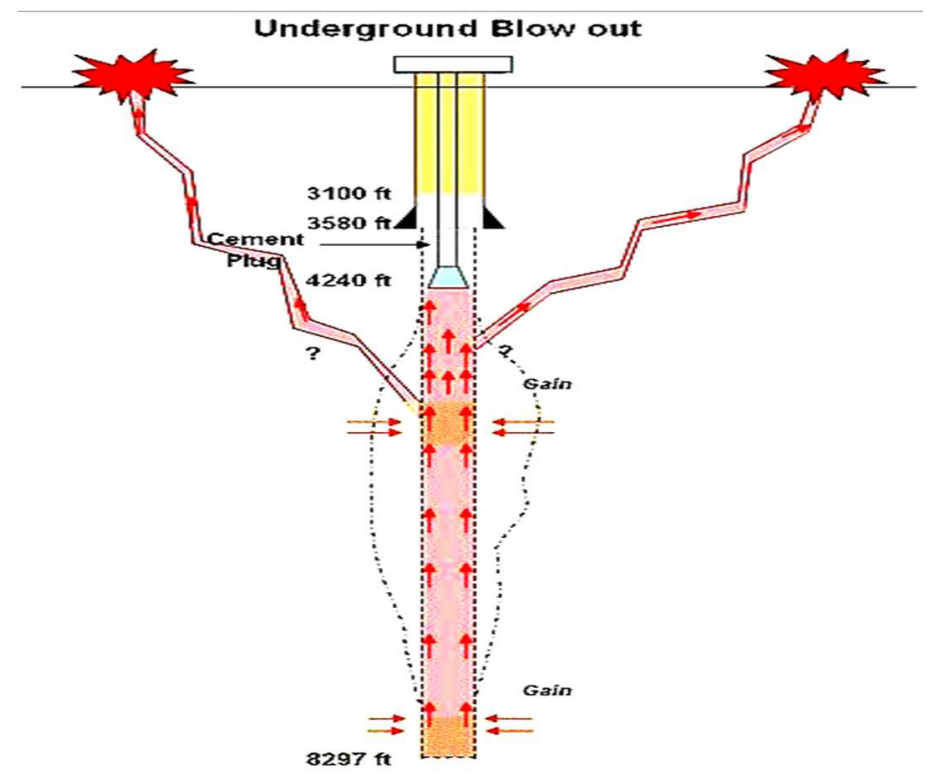

Sejalan dengan itu, Liek Wilardjo mengingatkan, bahwa setiap manusia adalah hidup di planet yang anta (finite), namun manusia selalu berulah seolaholah sumber daya alam yang ada di bumi ananta (infinite) tidak akan habis, negaranegara Timur dan Selatan yang terbelakang dan miskin tidak dapat mencegah ledakan penduduk, sedangkan negara-negara Barat dan Utara yang maju dan kaya tidak dapat menahan nafsu konsumtifnya. ${ }^{4}$ Oleh sebab itu, di tengah dinamika

\footnotetext{
3 https://id.wikipedia.org.," Banjir Lumpur Panas Sidoarjo", diakses pada 14 Juli 2016.

${ }^{4}$ Liek Wilardjo, Menerawang di Kala Senggang, Fakultas Teknik Elektro dan Program Pascasarjana Studi Pembangunan Universitas Kristen Satya Wacana, Salatiga, 2009, hlm.14.
} 
keterbatasan sumber daya energi tersebut dibutuhkan upaya pengelolaan sumber daya energi berbasis lingkungan hidup.

Berdasarkan pendapat Liek Wilardjo di atas, seakan seluruh elemen dan rakyat Indonesia diajak untuk sejenak merenungkan bahwa sesungguhnya dibalik kebutuhan energi yang cenderung semakin meningkat ada kebutuhan yang jauh lebih penting untuk kehidupan seluruh umat manusia termasuk seluruh rakyat Indoesia, yakni kebutuhan manusia terhadap kelestarian lingkungan hidup. Bertolak dari uraian di atas, muncul problematika pengelolaan sumber daya energi berbasis lingkungan hidup bagi rakyat Indonesia.

\section{Rumusan Masalah}

Berdasarkan latar belakang di atas, penelitian ini akan mengkaji: pertama, bagaimana politik hukum pengelolaan sumber daya energi saat ini? Kedua, bagaimana inkoherensi politik hukum pengelolaan sumber daya energi mengancam kelestarian lingkungan hidup? Ketiga, bagaimana politik hukum pengelolaan sumber daya energi yang berbasis lingkungan hidup di masa depan?

\section{Tujuan Penelitian}

Penelitian ini bertujuan untuk mengetahui dan menganalisis: pertama, politik hukum pengelolaan sumber daya energi saat ini. Kedua, inkoherensi politik hukum pengelolaan sumber daya energi mengancam kelestarian lingkungan hidup. Ketiga, politik hukum pengelolaan sumber daya energi yang berbasis lingkungan hidup di masa depan.

\section{Metode Penelitian}

Dalam penelitian ini digunakan metode yuridis normatif. Pendekatan penelitian menggunakan pendekatan perundang-undangan dan pendekatan kasus. Dalam penelitian ini data yang diperlukan adalah data sekunder, yaitu data yang bukan diusahakan sendiri pengumpulannya oleh peneliti. ${ }^{5}$ Data sekunder berupa bahan hukum primer, bahan hukum sekunder dan bahan hukum tertier. Bahan hukum primer berupa peraturan perundang-undangan terkait dengan

${ }^{5}$ Soerjono Soekamto, Pengantar Penelitian Hukum, UI Press, Jakarta, 2006, hlm. 51Peter Mahmud Marzuki, Op. Cit., hlm. 56. 
materi muatan yang diteliti dan dikaji, putusan pengadilan (Putusan MK terkait pembatalan perundang-undangan di tingkat pusat), yurisprudensi terkait. Bahan hukum sekunder berupa laporan-laporan dan data tertulis terkait dengan kajian yang akan dibahas, jurnal dan text book terkait materi kajian. Bahan hukum tersier berupa kamus hukum. Untuk memberikan penajaman dan elaborasi data lebih lanjut dilakukan Focus Group Discussion (FGD) dengan melibatkan pihak-pihak pemangku kepentingan. Data sekunder menggunakan identifikasi isi dengan metode studi kepustakaan, dimana metode ini digunakan dalam rangka memperoleh data sekunder, yaitu mengumpulkan data berupa buku-buku ilmiah yang berhubungan dengan masalah yang diteliti, dokumen-dokumen, peraturan perundangan yang sesuai dan lain sebagainya dengan membaca dan mengkajinya. Dalam penelitian ini digunakan teknik analisis kualitatif, mengingat data yang terkumpul sebagian besar merupakan data kualitatif. Metode kualitatif ini digunakan karena beberapa pertimbangan. Pertama, menyesuaikan metode kualitatif lebih mudah apabila berhadapan dengan kenyataan ganda. Kedua, metode ini lebih dapat menyesuaikan diri dengan banyak penajaman pengaruh bersama dan terhadap pola-pola nilai yang dihadapi. ${ }^{6}$

\section{Hasil Penelitian dan Pembahasan}

\section{Politik Hukum Pengelolaan Sumber Daya Energi di Indonesia}

Secara eksplisit definisi lingkungan hidup dijelaskan di dalam Pasal 1 angka 1, 2 dan 3 UU No. 32 Tahun 2009 tentang Perlindungan dan Pengelolaan Lingkungan Hidup (PPLH) adalah kesatuan ruang dengan semua benda, daya keadaan, dan makhluk hidup termasuk manusia dan perilakunya yang mempengaruhi alam itu sendiri, kelangsungan perikehidupan, dan kesejahteraan manusia serta makhluk hidup lain. Oleh karena itu, untuk mencegah kerusakan lingkungan hidup sebagai akibat dari pengelolaan sumber daya energi perlu adanya upaya perlindungan dan pengelolaan lingkungan hidup, melalui pembangunan berkelanjutan yang menjamin keutuhan lingkungan hidup, serta keselamatan kemampuan, kesejahteraan, dan mutu hidup generasi masa kini dan generasi masa depan.

\footnotetext{
${ }^{6}$ Lexy J. Moleong, Metodologi Penelitian Kualitatif, PT. Remaja Pusdakarya, Bandung, 2007, hlm. 10.
} 
Secara konseptual salah satu pilar grand design sistem dan politik hukum nasional adalah prinsip bahwa hukum mengabdi pada kepentingan bangsa untuk memajukan negara dan menjadi pilar demokrasi serta tercapainya kesejahteraaan rakyat. ${ }^{7}$ Berkembangnya tuntutan yang meluas agar kebijakan-kebijakan resmi negara yang pro lingkungan dapat tercermin dalam bentuk perundang-undangan yang mengikat untuk ditaati oleh semua pemangku kepentingan (stakeholders). ${ }^{8}$ Dengan demikian, politik hukum pengelolaan sumber daya energi semestinya berbasis kepada lingkungan hidup.

Senada dengan grand design di atas, secara filosofis di dalam pertimbangan umum UU 32 Tahun 2009 tentang PPLH ditegaskan bahwa pada dasarnya lingkungan hidup yang baik dan sehat merupakan hak asasi setiap warga negara Indonesia yang dijamin oleh konstitusi Pasal 28H UUD NRI Tahun 1945, hanya dapat dicapai dengan diselenggarakannya pembangunan ekonomi berdasarkan prinsip pembangunan berkelanjutan dan berwawasan lingkungan sesuai Pasal 33 ayat (4) UUD NRI Tahun 1945.

Pemikiran politik hukum seperti itu sejalan dengan prinsip pembangunan berkelanjutan dan berwawasan lingkungan yang disepakati di dalam deklarasi dan perjanjian internasional melalui konferensi PBB tentang Lingkungan dan Pembangunan (United Nation Conference on Environment and Development) di Rio de Janiero, Tahun 1992, sebagaimana dikutip oleh Adji Samekto, sebagai berikut:9 a. prinsip keadilan antar generasi (intergenerational equity); b. prinsip keadilan dalam satu generasi (intragenerational equity); c. prinsip pencegahan dini (Precautionary); $\mathrm{d}$. prinsip perlindungan keragaman hayati (conservation of biological diversity); e. prinsip internalisasi biaya lingkungan.

Namun demikian, pengelolaan Sumber Daya Energi (SDE) di Indonesia cenderung kontraproduktif dengan apa yang digariskan oleh United Nation

\footnotetext{
${ }^{7}$ Barda Nawawi Arief, "Kumpulan Hasil Seminar Hukum Nasional Ke I s/d VIII dan Konvensi Hukum Nasional 2008 tentang UUD 1945 Sebagai Landasan Konstitusional Grand Design Sistem dan Politik Hukum Nasional”, Cetakan Ketiga, Badan Penerbit Universitas Diponegoro Pustaka Magister, Semarang, 2011, hlm. 133-134.

${ }^{8}$ I Gusti Ayu Ketut Rachmi Handayani, "Penguatan Fungsi Lingkungan Hidup Melalui Penegakan Hukum Lingkungan Sesuai Undang-Undang Nomor 32 Tahun 2009 tentang Perlindungan dan Pengelolaan Lingkungan Hidup", Yustisia, Nomor 78, September-Desember 2009, hlm. 74.

${ }^{9}$ FX. Adji Samekto, Keterkaitan Kapitalisme Dengan Konsep Pembangunan Berkelanjutan dan Implementasi Konvensi Keanekaragaman Hayati dalam Kajian Studi Hukum Kritis (Critical Legal Studies), Undip, Semarang, 2003, hlm.150-151.
} 
Conference on Environment and Development serta prinsip-prinsip pembangunan berkelanjutan dan berwawasan lingkungan yang digariskan oleh konstitusi negara RI di atas, ecara normative gejala mal kelola SDE tersebut dapat diketemukan di dalam beberapa undang-undang terkait energi sebagai berikut:

Tabel 1: Politik Hukum Pengelolaan SDE Migas saat ini ${ }^{10}$

\begin{tabular}{|c|c|c|c|}
\hline Aspek Hukum & $\begin{array}{l}\text { UU No. } 44 / 60 \text { dan } \\
\text { UU No. } 8 / 71\end{array}$ & UU No. 22/2001 & Uraian \\
\hline $\begin{array}{l}\text { 1. Landasan } \\
\text { Konstitusi }\end{array}$ & $\begin{array}{l}\text { Pasal } 33 \text { UUD } \\
\text { Negara RI Tahun } \\
1945\end{array}$ & $\begin{array}{l}\text { Pasal } 33 \text { UUD } \\
\text { Negara RI } \\
\text { Tahun } 1945\end{array}$ & $\begin{array}{l}\text { Substansi UU Migas tidak } \\
\text { berdasarkan Pasal } 33 \text { UUD } \\
\text { Negara RI Tahun } 1945 \text { dan } \\
\text { Pasal } 51 \text { UU No. } 5 \text { Tahun } \\
1999\end{array}$ \\
\hline $\begin{array}{l}\text { 2. Falsafah } \\
\text { Usaha Migas }\end{array}$ & $\begin{array}{l}\text { Pengelolaan dan } \\
\text { Pengusahaan migas } \\
\text { untuk } \\
\text { Sebesar-besarnya } \\
\text { kemakmuran rakyat }\end{array}$ & $\begin{array}{l}\text { Pengelolaan dan } \\
\text { Pengusahaan } \\
\text { migas atas dasar } \\
\text { kepemilikan } \\
\text { investasi } \\
\text { asing/swasta } \\
\text { dan persaingan } \\
\text { bebas (Pasal } 12 \\
\text { ayat (3)) }\end{array}$ & $\begin{array}{l}\text { Bertentangan dengan } \\
\text { Pasal } 33 \text { UUD Negara RI } \\
\text { Tahun 1945, karena } \\
\text { perusahaan asing akan } \\
\text { menguasai industri Migas } \\
\text { nasional. }\end{array}$ \\
\hline $\begin{array}{l}\text { 3. Kuasa Usaha } \\
\text { Pertambanga } \\
\text { n/ Kuasa } \\
\text { Pertambanga } \\
\text { n Migas }\end{array}$ & $\begin{array}{l}\text { Meliputi: Eksplorasi, } \\
\text { Eksploitasi, } \\
\text { pemurnian dan } \\
\text { Pengolahan, } \\
\text { Pengangkutan dan } \\
\text { Penjualan (UU } \\
\text { No.44 Tahun 1960) }\end{array}$ & $\begin{array}{l}\text { Meliputi: } \\
\text { Eksplorasi dan } \\
\text { Eksploitasi }\end{array}$ & $\begin{array}{l}\text { Bertentangan dengan } \\
\text { Pasal } 33 \text { UUD Negara RI } \\
\text { Tahun 1945, karena hasil } \\
\text { kegiatan Pemurnian, } \\
\text { Pengolahan, } \\
\text { Pengangkutan dan } \\
\text { Penjualan mempengaruhi } \\
\text { hajat hidup orang banyak. }\end{array}$ \\
\hline $\begin{array}{l}\text { 4. Migas } \\
\text { sebagai } \\
\text { sumber daya } \\
\text { alam } \\
\text { startegis } \\
\text { (Pasal } 33 \\
\text { Ayat (3) } \\
\text { UUD Negara } \\
\text { RI Tahun } \\
\text { 1945) }\end{array}$ & $\begin{array}{l}\text { Kuasa Usaha } \\
\text { Pertambangan } \\
\text { Migas diberikan } \\
\text { kepada Perusahaan } \\
\text { Negara. (Pasal 11 } \\
\text { ayat (1) dan (2) UU } \\
\text { No. } 8 \text { Tahun 1971 }\end{array}$ & $\begin{array}{l}\text { Kuasa/wewena } \\
\text { ng melakukan } \\
\text { kegiatan usaha } \\
\text { eksplorasi dan } \\
\text { eksploitasi } \\
\text { diserahkan oleh } \\
\text { Pemerintah } \\
\text { langsung } \\
\text { kepada investor } \\
\text { swasta (asing } \\
\text { dan nasional) } \\
\end{array}$ & $\begin{array}{l}\text { Bertentangan dengan } \\
\text { Pasal } 33 \text { UUD Negara RI } \\
\text { Tahun 1945, karena negara } \\
\text { hanya mengatur dan } \\
\text { mengawai eksplorasi dan } \\
\text { eksploitasi dan negara } \\
\text { tidak menguasainya. }\end{array}$ \\
\hline
\end{tabular}

${ }^{10}$ Edi As'Adi, Rekonstruksi Regulasi Energi Nasional Dalam Melindungi Hak Rakyat Atas Energi Berbasis Hukum Progresif; Studi Regulasi Harga Keekonomian Bahan Bakar Minyak Bersubsidi, Undip, Semarang, 2015, hlm. 219-224. 


\begin{tabular}{|c|c|c|c|}
\hline $\begin{array}{l}\text { 5. Cabang } \\
\text { produksi } \\
\text { yang penting } \\
\text { dan } \\
\text { menguasai } \\
\text { hajat hidup } \\
\text { orang } \\
\text { banyak. }\end{array}$ & $\begin{array}{l}\text { Dilaksanakan hanya } \\
\text { oleh Perusahaan } \\
\text { Negara sebagai } \\
\text { Kuasa Usaha } \\
\text { Pertambangan }\end{array}$ & $\begin{array}{l}\text { Diserahkan } \\
\text { kepada } \\
\text { mekanisme pasar } \\
\text { dalam usaha } \\
\text { liberalisasi }\end{array}$ & $\begin{array}{l}\text { Bertentangan dengan } \\
\text { Pasal } 33 \text { UUD Negara RI } \\
\text { Tahun 1945, karena } \\
\text { cabang produksi yang } \\
\text { penting dan menguasai } \\
\text { hajat hidup orang banyak } \\
\text { diserahkan kepada } \\
\text { perusahaan milik orang } \\
\text { perorang (swasta } \\
\text { asing/nasional) }\end{array}$ \\
\hline $\begin{array}{l}\text { 6. Pola Industri } \\
\text { Migas } \\
\text { Nasional }\end{array}$ & $\begin{array}{l}\text { Terintegrasi dan } \\
\text { tidak mengenal } \\
\text { istilah hulu dan hilir } \\
\text { (Pasal } 6 \text { ayat }(1))\end{array}$ & $\begin{array}{l}\text { Hulu dipisahkan } \\
\text { dari hilir } \\
\text { (unbundling) } \\
\text { (Pasal 10) }\end{array}$ & $\begin{array}{l}\text { Biaya/harga produk BBM } \\
\text { dan non BBM akan lebih } \\
\text { mahal karena setiap } \\
\text { sektor kegiatan } \\
\text { mempunyai biaya dan } \\
\text { profit tersendiri. Hal ini } \\
\text { juga bertentangan dengan } \\
\text { trend industri migas } \\
\text { dunia. }\end{array}$ \\
\hline $\begin{array}{l}\text { 7. Bentuk } \\
\text { BUMN } \\
\text { Migas }\end{array}$ & $\begin{array}{l}\text { Berdasarkan UU } \\
\text { tersendiri sesuai } \\
\text { Pasal } 1 \text { UU No. } 9 \\
\text { Tahun } 1969\end{array}$ & $\begin{array}{l}\text { BUMN Persero } \\
\text { berdasarkan PP } \\
\text { menyimpang dari } \\
\text { UU No. } 1 \text { Tahun } \\
\text { 1995tentang } \\
\text { Perseroan }\end{array}$ & $\begin{array}{l}\text { BUMN Migas (Persero) } \\
\text { harus tunduk kepada } \\
\text { UU No. } 5 \text { Tahun } 1999\end{array}$ \\
\hline $\begin{array}{l}\text { 8. Fungsi } \\
\text { Perusahaan } \\
\text { Negara } \\
\text { Migas }\end{array}$ & $\begin{array}{l}\text { Melaksanakan } \\
\text { sendiri usaha migas } \\
\text { dari hulu sampai } \\
\text { hilir }\end{array}$ & $\begin{array}{l}\text { Harus menjadi } \\
\text { kontraktor Badan } \\
\text { Pelaksana } \\
\text { (BHMN), sedang } \\
\text { di hilir hanya } \\
\text { setelah } \\
\text { memperoleh izin } \\
\text { dari Badan } \\
\text { Pengatur, } \\
\text { termasuk } \\
\text { kegiatan yang } \\
\text { menggunakan } \\
\text { asset perusahaan } \\
\text { negara sendiri. } \\
\text { (Pasal 60) }\end{array}$ & $\begin{array}{l}\text { Negara tidak lagi } \\
\text { menyelanggarakan } \\
\text { pengusahaan Migas } \\
\text { karena wewenang } \\
\text { melakukan kegiatan } \\
\text { eksplorasi dan ekploitasi } \\
\text { diserahkan Pemerintah } \\
\text { langsung kepada swasta } \\
\text { (asing/nasional). Pada } \\
\text { kegiatan sektor hilir } \\
\text { melalui perizinan, } \\
\text { kegiatan dilakukan } \\
\text { berdasarkan mekanisme } \\
\text { pasar. }\end{array}$ \\
\hline $\begin{array}{l}\text { 9.Ciri usaha } \\
\text { migas yang } \\
\text { diinginkan }\end{array}$ & $\begin{array}{l}\text { Bukan monopoli, } \\
\text { namun PP mengenai } \\
\text { pengaturanharga } \\
\text { BBM membuat } \\
\text { perusahaan swasta } \\
\text { (asing/nasional) } \\
\text { tidak tertarik untuk } \\
\text { masuk ke pasar } \\
\text { BBM dalam negeri }\end{array}$ & $\begin{array}{l}\text { Bukan monopoli, } \\
\text { selama daya beli } \\
\text { masyarakat di } \\
\text { bawah harga } \\
\text { pasar, } \\
\text { perusahaan baru } \\
\text { tidak ingin } \\
\text { masuk dan } \\
\text { monopoli akan }\end{array}$ & $\begin{array}{l}\text { Liberalisasi pasar BBM } \\
\text { dalam negeri tidak } \\
\text { tercapai selama daya beli } \\
\text { masyarakat masih di } \\
\text { bawah harga pasar. }\end{array}$ \\
\hline
\end{tabular}




\begin{tabular}{|c|c|c|c|}
\hline & $\begin{array}{l}\text { (Pasal 13b UU No. } 8 \\
\text { Tahun 1971) }\end{array}$ & berlanjut. & \\
\hline $\begin{array}{l}\text { 10. Lingkup } \\
\text { Kontrak } \\
\text { Kerjasama }\end{array}$ & $\begin{array}{l}\text { Meliputi kegiatan } \\
\text { eksplorasi, } \\
\text { eksploitasi, } \\
\text { pemurnian dan } \\
\text { pengolahan, } \\
\text { pengangkutan dan } \\
\text { penjualan (Kontrak } \\
\text { Karya). Atas } \\
\text { kebijakan devisa } \\
\text { tertutup oleh } \\
\text { pemerintah, pihak } \\
\text { asing hanya } \\
\text { meneruskan kerja } \\
\text { sama dalam } \\
\text { kegiatan eksplorasi } \\
\text { dan eksploitasi dan } \\
\text { menarik diri dari } \\
\text { kegiatan hilir serta } \\
\text { menjual semua } \\
\text { assetnya kepada } \\
\text { BUMN. }\end{array}$ & $\begin{array}{l}\text { Meliputi } \\
\text { kegiatan } \\
\text { eksplorasi dan } \\
\text { eksploitasi }\end{array}$ & $\begin{array}{l}\text { Kegiatan pemurnian dan } \\
\text { pengolahan pengangkutan } \\
\text { dan penjualan tidak perlu } \\
\text { kerja sama dan hanya } \\
\text { diberi izin oleh } \\
\text { pemerintah, hal mana } \\
\text { bertentangan dengan } \\
\text { Pasal } 33 \text { UUD Negara RI } \\
\text { Tahun } 1945 .\end{array}$ \\
\hline $\begin{array}{l}\text { 11.Lapangan } \\
\text { kerja di } \\
\text { Daerah } \\
\text { Penghasil } \\
\text { Migas }\end{array}$ & $\begin{array}{l}\text { Bentuk usaha } \\
\text { terintegrasi dari } \\
\text { pemerintah masih } \\
\text { menjamin } \\
\text { berlangsungnya } \\
\text { pengusahaan } \\
\text { lapangan-lapangan } \\
\text { minyak marginal di } \\
\text { daerah. }\end{array}$ & $\begin{array}{l}\text { Memaksa } \\
\text { penutupan } \\
\text { lapangan- } \\
\text { lapangan } \\
\text { minyak } \\
\text { marginal saat } \\
\text { harga Migas } \\
\text { turun. }\end{array}$ & $\begin{array}{l}\text { Peningkatan } \\
\text { pengangguran di daerah } \\
\text { lapangan marginal dan } \\
\text { ditutupnya kilang } \\
\text { pengolahan kecil. }\end{array}$ \\
\hline $\begin{array}{l}\text { 12.Pengaturan } \\
\text { dan } \\
\text { pengawasan }\end{array}$ & $\begin{array}{l}\text { Dilakukan oleh } \\
\text { Pemerintah sendiri } \\
\text { (Pasal 16 UU No. } 44 \\
\text { Tahun 1960) }\end{array}$ & $\begin{array}{l}\text { Dilakukan oleh } \\
\text { Badan Pengatur } \\
\text { yang dibentuk } \\
\text { oleh Pemerintah } \\
\text { (Pasal } 44 \text { dan 46) }\end{array}$ & $\begin{array}{l}\text { Tumpang tindih dengan } \\
\text { DESDM c/o Ditjen Migas } \\
\text { serta menambah } \\
\text { pengeluaran negara. }\end{array}$ \\
\hline $\begin{array}{l}\text { 13.Kepentingan } \\
\text { Daerah }\end{array}$ & $\begin{array}{l}\text { a. Peran Pemda } \\
\text { terdapat dalam } \\
\text { Persetujuan } \\
\text { AMDAL, masalh } \\
\text { tanah, } \\
\text { pengaturanHET } \\
\text { minyak tanah dan } \\
\text { penerimaan } \\
\text { sebagian } \\
\text { perolehan Negara. }\end{array}$ & $\begin{array}{l}\text { a. Peran Pemda } \\
\text { terdapat dalam } \\
\text { Persetujuan } \\
\text { AMDAL, } \\
\text { masalh tanah, } \\
\text { pengaturan } \\
\text { HET minyak } \\
\text { tanah dan } \\
\text { penerimaan } \\
\text { sebagian } \\
\text { perolehan } \\
\text { Negara. }\end{array}$ & $\begin{array}{l}\text { a. Harga BBM ditentukan } \\
\text { pasar dan akan } \\
\text { berbeda-beda pada } \\
\text { setiap daerah. } \\
\text { b. Perolehan Daerah } \\
\text { Tingkat I dan II } \\
\text { tergantung hasil } \\
\text { perundingan pejabat } \\
\text { DESDM yang tidak } \\
\text { memiliki akuntabilitas } \\
\text { public. }\end{array}$ \\
\hline
\end{tabular}




\begin{tabular}{|c|c|c|c|}
\hline & $\begin{array}{l}\text { b. Perolehan daerah } \\
\text { tingkat I dan II } \\
\text { dari penerimaan } \\
\text { Negara terjamin } \\
\text { besarannya } \\
\text { karena adanya } \\
\text { jaminan } \\
\text { penerimaan } \\
\text { Negara minimal } \\
60 \% \text { dari } \\
\text { penerimaan bersih } \\
\text { usaha KPS } \\
\text { Pertamina. }\end{array}$ & $\begin{array}{l}\text { b. Tidak } \\
\text { terdapat } \\
\text { jaminan } \\
\text { penerimaan } \\
\text { negara. }\end{array}$ & $\begin{array}{l}\text { c. Pemda tidak lagi } \\
\text { menentukan HET } \\
\text { minyak tanah di } \\
\text { wilayahnya. }\end{array}$ \\
\hline 14.Harga BBM & $\begin{array}{l}\text { Ditetapkan oleh } \\
\text { Pemerintah (Pasal } \\
\text { 13b) }\end{array}$ & $\begin{array}{l}\text { Diserahkan } \\
\text { pada Persaingan } \\
\text { Usaha } \\
\text { (Mekanisme } \\
\text { Pasar) (Pasal } 28 \\
\text { ayat (2)) }\end{array}$ & $\begin{array}{l}\text { a. Timbul perbedaan } \\
\text { harga antar } \\
\text { daerah/pulau yang } \\
\text { dapat memicu } \\
\text { disintegrasi bangsa dan } \\
\text { menimbulkan } \\
\text { kecemburuan sosial. } \\
\text { b. Bertentangan dengan } \\
\text { praktek kebijaksanaan } \\
\text { harga BBM di setiap } \\
\text { negaradi mana } \\
\text { pemerintah ikut } \\
\text { mengatur harga BBM } \\
\text { sesuai dengan } \\
\text { kebijaksanaan energi } \\
\text { dan ekonomi nasional } \\
\text { setiap negara, komoditas } \\
\text { BBM tidak termasuk } \\
\text { dalam agenda WTO. }\end{array}$ \\
\hline $\begin{array}{l}\text { 15.Pengaturan } \\
\text { Pengawasan } \\
\text { (Regulator } \\
\text { dan } \\
\text { Pengawas) }\end{array}$ & $\begin{array}{l}\text { a. Dilakukan oleh } \\
\text { Pemerintah } \\
\text { seluruhnya (Pasal } \\
16 \text { UU No. 44/60) } \\
\text { b. Pertamina bukan } \\
\text { regulator, hanya } \\
\text { Pemegang kendali } \\
\text { management KPS, } \\
\text { Penetapan } \\
\text { wilayah kerja dan } \\
\text { penandatangan } \\
\text { kontrak dengan } \\
\text { KPS hanya dapat } \\
\text { dilakukan setelah } \\
\text { memperoleh } \\
\text { persetujuan } \\
\text { Pemerintah }\end{array}$ & $\begin{array}{l}\text { Pengawasan } \\
\text { dan Pengaturan } \\
\text { sebagian } \\
\text { diserahkan } \\
\text { kepada badan- } \\
\text { badan ekstra } \\
\text { structural } \\
\text { (Badan } \\
\text { Pelaksana dan } \\
\text { badan Pengatur) } \\
\text { yang masing- } \\
\text { masing } \\
\text { bertanggung } \\
\text { jawab kepada } \\
\text { Presiden seperti } \\
\text { juga masing- } \\
\text { masing menteri. }\end{array}$ & $\begin{array}{l}\text { Pada implementasinya } \\
\text { akan menimbulkan } \\
\text { kekacauan dan kerancuan } \\
\text { mengenai pertanggung } \\
\text { jawaban (akuntabilita) } \\
\text { publik }\end{array}$ \\
\hline
\end{tabular}




\begin{tabular}{clll}
\hline $\begin{array}{c}\text { 16.Keterkaitan } \\
\text { Pada }\end{array}$ & Pengalokasian & Karena harga & SDE non minyak akan \\
Sumber & sumber daya energi & BBM diserahkan & semakin sulit untuk \\
Energi Lain & dimungkinkan & pada & dikembangkan karena \\
& dilakukan oleh & harga pasar, & pengembangannya \\
& Pmerintah lewat & maka & harga BBM yang sudah \\
kebijaksanaan harga & pemerintah & sepenuhnya diserahkan \\
& BBM. & tidak punya & kepada mekanisme pasar. \\
& & sarana untuk & \\
& & pengalokasian & \\
& & SDE lainnya. &
\end{tabular}

Sumber: diolah dari Putusan Mahkamah Konstitusi Nomor 002/PUU-I/2003

Liberalisasi dan kapitalisasi pengaturan pengelolaan sumber daya energi nasional tidak hanya terjadi pada sektor minyak dan gas bumi seperti disebutkan didalam tabel di atas, namun juga terjadi di sektor ketenagalistrikan seperti dilihat di dalam Undang-Undang 30 Tahun 2007 Tentang Energi berikut ini:

Tabel 2 : Politik Hukum Pengelolaan SDE menurut UU No. 30 Tahun 2007, UU No. 8 Tahun 1971 dan UU 22 Tahun 201111

\begin{tabular}{|c|c|c|c|c|}
\hline No & Aspek & $\begin{array}{c}\text { UU No. } 8 \\
\text { Tahun } 1971\end{array}$ & $\begin{array}{l}\text { UU No. } 22 \text { Tahun } \\
2001\end{array}$ & $\begin{array}{l}\text { UU No. } 30 \text { Tahun } \\
2007\end{array}$ \\
\hline 1 & Materi & $\begin{array}{l}\text { Tentang } \\
\text { Pertambangan } \\
\text { Minyak dan Gas } \\
\text { Bumi, } 14 \text { bab } \\
\text { dan } 34 \text { pasal }\end{array}$ & $\begin{array}{l}\text { Minyak dan Gas } \\
\text { Bumi; } 14 \text { bab dan } \\
67 \text { pasal }\end{array}$ & $\begin{array}{l}\text { Sumber daya energi; } \\
10 \text { bab dan } 34\end{array}$ \\
\hline 2 & $\begin{array}{l}\text { Fungsi } \\
\text { Minyak }\end{array}$ & $\begin{array}{l}\text { Untuk } \\
\text { Perekonomian } \\
\text { negara dan } \\
\text { kepentingan } \\
\text { pertahanan dan } \\
\text { keamanan } \\
\text { nasional }\end{array}$ & $\begin{array}{l}\text { Untuk } \\
\text { pembangunan } \\
\text { nasional dan } \\
\text { kesejahteraan } \\
\text { rakyat }\end{array}$ & $\begin{array}{l}\text { peningkatan } \\
\text { kegiatan ekonomi } \\
\text { dan ketahanan } \\
\text { nasional }\end{array}$ \\
\hline 3 & Sistem & $\begin{array}{l}\text { Sentralistik/ } \\
\text { Top-down }\end{array}$ & Sentralistik & sentralistik \\
\hline 4 & Pemerintah & Provider & $\begin{array}{l}\text { Pemegang kuasa } \\
\text { pertambangan }\end{array}$ & regulator (Pasal 4) \\
\hline 5 & $\begin{array}{l}\text { Peran serta } \\
\text { masyarakat }\end{array}$ & $\begin{array}{l}\text { Ada namun } \\
\text { tidak menonjol }\end{array}$ & $\begin{array}{l}\text { Ada dengan } \\
\text { dilibatkannya } \\
\text { masyarakat } \\
\text { menjalankan } \\
\text { kegiatan usaha }\end{array}$ & $\begin{array}{l}\text { Ada, dalam hak dan } \\
\text { kewajiban (Pasl } 19 \\
\text { Ayat } 1 \text { dan Ayat 2) } \\
\text { melalui penyerapan } \\
\text { tenaga kerja dan }\end{array}$ \\
\hline
\end{tabular}

${ }^{11}$ Edi As'Adi, Ibid., hlm. 2013. 


\begin{tabular}{|c|c|c|c|c|}
\hline & & & $\begin{array}{l}\text { hulu dan hilir } \\
\text { (Pasal 9) }\end{array}$ & $\begin{array}{l}\text { pendidikan untuk } \\
\text { menigkatkan } \\
\text { prfesionalitas suber } \\
\text { daya manusia dan } \\
\text { partisipasi } \\
\text { masyarakat untuk } \\
\text { menjadi anggota } \\
\text { Dewan Energi } \\
\text { Nasional }\end{array}$ \\
\hline 6 & $\begin{array}{l}\text { Perijinan } \\
\text { Kegiatan } \\
\text { Usaha }\end{array}$ & $\begin{array}{l}\text { Diatur melalui } \\
\text { rapat RUPS dan } \\
\text { persetujuan } \\
\text { presiden }\end{array}$ & $\begin{array}{l}\text { Izin usaha Hulu } \\
\text { diberikan melalui } \\
\text { kontrak kerja sama } \\
\text { dan izin usaha hilir } \\
\text { dipermudah } \\
\text { dengan pemberian } \\
\text { izin usaha } \\
\text { pengolahan, } \\
\text { pengangkutan, } \\
\text { penyimpanan dan } \\
\text { usaha niaga. (Pasal } \\
\text { 23) }\end{array}$ & $\begin{array}{l}\text { Izin Usaha Energi } \\
\text { diberikan oleh } \\
\text { pemerintah kepada } \\
\text { badan usaha }\end{array}$ \\
\hline 7 & $\begin{array}{l}\text { Ketentuan } \\
\text { Baru }\end{array}$ & & $\begin{array}{l}\text { Pemisahan } \\
\text { kegiatan usaha } \\
\text { hulu dengan hilir, } \\
\text { pengaturan harga } \\
\text { minyak ditentukan } \\
\text { oleh pasar minyak } \\
\text { dunia, kewajiban } \\
\text { pemerintah dan } \\
\text { pemerintah daerah } \\
\text { memberikan } \\
\text { subsidi bagi rakyat } \\
\text { tidak mampu }\end{array}$ & $\begin{array}{l}\text { Patokan pengaturan } \\
\text { harga energi } \\
\text { didasarkan kepada } \\
\text { prinsip keekonomian } \\
\text { berkeadilan (Pasal 7) }\end{array}$ \\
\hline
\end{tabular}

Berdasarkan uraian tabel 1 dan 2 di atas, dapat disimpulkan bahwa pada dasarnya politik hukum pengelolaan SDE yang ada saat ini cenderung lebih mengutamakan nilai keuntungan ekonomi ketimbang nilai kelestarian lingkungan hidup. Dengan demikian, bila hal semacam itu dibiarkan terus berjalan maka dikhawatirkan kerusakan lingkungan hidup akan semakin meluas dan massif. Oleh karena itu, untuk mencegah terjadinya kerusakan lingkungan diperlukan kemauan politik dari para pemimpin negara untuk menciptakan energi bersih (clean energy). 
Terkait dengan uraian tabel di atas, upaya pengelolaan SDE yang berbasis lingkungan hidup pada dasarnya telah menjadi agenda-agenda internasional dan nasional selama ini, baik yang dimulai dari deklarasi Stockholm 28 Mei 1968, Deklarasi Rio de Janeiro 3 s/d 14 Juni 1992 (dalam WCED, UNCED, UNFCCC), KTT WSSD 2-12 September 2002 di Johannesburg dan Deklarasi Quebec, Kanada Mei 2002,12 selanjutnya dalam (Conference of Parties/COP) Ke-21 Konvensi Kerangka Kerja PBB tentang Perubahan Iklim di Paris, 29 November 2015, Presiden Barack Obama akan meluncurkan Clean Energy Initiative dengan mengajak 19 negara, termasuk Indonesia. ${ }^{13}$ Dengan demikian, paradigma politik hukum pengelolaan SDE yang saat ini cenderung berorientasi ekonomi sudah saatnya digeser kepada paradigma kelestarian lingkungan hidup.

\section{Inkoherensi Politik Hukum Pengelolaan Sumber Daya Energi Mengancam Kelestarian Lingkungan Hidup}

Seperti telah dijelaskan pada bagian di atas, bahwa mal kelola SDE dapat dikatakan sebagai bentuk pengabaian terhadap kelestarian lingkungan hidup. Tindakan demikian tentu merupakan salah satu bentuk pelanggaran hak asasi manusia yang dijamin konstitusi Pasal 28 H ayat (1) UUD 1945 serta UndangUndang 32 Tahun 2009 tentang Perlindungan dan Pengelolaan Lingkungan Hidup.

Semestinya pelanggaran konstitusi dalam pengelolaan SDE dapat diminimalisir bilamana politik hukum pengelolaan SDE senantiasa berbasis lingkungan hidup. Seperti ditegaskan dalam Pasal 44 paragraf 9 tentang Peraturan Perundang-undangan Berbasis Lingkungan Hidup, selengkapnya berbunyi : Setiap penyusunan peraturan perundang-undangan pada tingkat nasional dan daerah wajib memperhatikan perlindungan fungsi lingkungan hidup dan prinsip perlindungan dan pengelolaan lingkungan hidup sesuai dengan ketentuan yang diatur dalam undang-undang ini.

Unsur lingkungan hidup menjadi salah satu unsur penting bagi keberhasilan bekerjanya hukum dari sebuah produk hukum terkait pengelolaan SDE. Menurut Talcott Parsons dalam teori sybernitika "Societies: Evolutionary and Comparative

12 I Gusti Ayu Ketut Rachmi Handayani, Pengantar Hukum Lingkungan, Cakrabooks, Surakarta, 2014, hlm.8-

13 https://m.tempo.co/read/news/2015/11/30/206723341/jokowi-diminta-bicara-energi-bersih-di-cop-

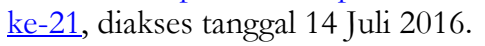


Perspectives" 1966 dan "The System of Moderen Societies" 1971, menjelaskan bahwa pergulatan di antara variabel-variabel bekerjanya hukum terjadi tarik menarik atau konflik antara faktor energi politis dan energi pasar atau ekonomi, dan dalam pembentukan hukum terkait pengelolaan SDE energi nasional kecenderungan yang paling kuat adalah variabel ekonomi dibandingkan politis. ${ }^{14}$

Politik hukum di era reformasi sampai dengan sekarang ini cenderung bernuansa liberalis kapitalisme, terbukti secara yuridis sudah cukup banyak fakta hukum yang menunjukkan terjadinya inkonsistensi politik hukum pengelolaan SDE yang cenderung menyimpang dari UUD NRI 1945, antara lain adalah Putusan Mahkamah Konstitusi RI No. 83/PUU-XI/2013 tentang pembayaran ganti rugi terhadap korban bencana lumpur Sidoarjo; Putusan Mahkamah Konstitusi RI No. 001-021/PUU-I/2003 tentang uji materiil UU No. 20 Tahun 2002 tentang Ketenagalistrikan; Putusan Mahkamah Konstitusi RI No.002/PUU-I/2003 tentang uji matriil UU No. 22 Tahun 2001 tentang Minyak dan Gas Bumi, Putusan Mahkamah Konstitusi RI No.36/PUU-X/2012 tentang uji materiil UU No. 22 Tahun 2001 tentang pembubaran BP Minyak dan Gas Bumi. ${ }^{15}$

Fakta hukum di atas juga menunjukkan bahwa kapitalisasi dan liberalisasi pengelolaan SDE di era reformasi selain cenderung dapat mengancam kelestarian lingkungan hidup, ternyata sangat bertentangan dengan konsep kemakmuran (welfare state) atau tujuan negara yang telah digariskan oleh landasan filosofis (filosofische grondslag) yang dirumuskan dalam cita-cita kebenaran (idée der waarheid) dan cita-cita keadilan (idée der gerechtigheid). ${ }^{16}$

\section{Politik Hukum Pengelolaan Sumber Daya Energi Yang Berbasis Lingkungan Hidup Di Masa Depan}

Berdasarkan uraian pada bagian sebelumnya dapat dikatakan bahwa politik hukum pengelolaan sumber daya energi yang berbasis lingkungan hidup di masa depan barangkali hanya dapat dicapai dengan meletakkan falsafah Pancasila (grundnorms) dan sekaligus sebagai dasar negara dan landasan filosofis (filosofische

\footnotetext{
${ }^{14}$ Edi AS'Adi, Ibid.

${ }^{15}$ Edi As'Adi, Ibid., baca juga dalam Sekjen dan Kepaniteraan Mahkamah Konstitusi RI, Himpunan Putusan Mahkamah Konstitusi Republik Indonesia, Mahkamah Konstitusi RI, Jakarta, 2004.

16 Amiroedin Syarif, Perundang-undangan Dasar, Jenis dan Tekhnik. Membuatnya, Bina Aksara, Jakarta, 1987, hlm. 91.
} 
grondslag) politik hukum energi nasional yang menjiwai setiap landasan hidup secara sosiologis dan yuridis. Politik hukum tertinggi terdapat dalam UUD NRI 1945 yang memuat arah kebijakan hukum yang harus dijalankan sesuai dengan tujuan nasional yang hendak dicapai dan berdasarkan pada Pancasila yang termaktub dalam Pembukaan UUD NRI 1945. Nilai-nilai dasar yang ada pada Pancasila sebagai rambu-rambu pembangunan hukum nasional terdiri dari empat kaidah penuntun hukum yang harus dipedomani dalam pembangunan hukum. Pertama, hukum yang dapat menjaga integrasi (keutuhan kesatuan) baik ideologi maupun teritori sesuai dengan tujuan nasiobal. Kedua, hukum nasional harus dibangun secara demokratis dan nomokratis, mengandung partisipasi dan menyerap aspirasi melalui mekanisme yang fair, transparan dan akuntabel. Ketiga, hukum nasional harus mampu menciptakan keadilan sosial, memperpendek jurang kesenjangan. Keempat, hukum harus menjamin toleransi beragama yang berkeadaban antar pemeluknya. ${ }^{17}$ Kaidah penuntun hukum tersebut harus dituangkan dalam tertib pembentukan peraturan perundang-undangan yang dirintis sejak saat perencanaan sampai dengan pengundangannya supaya tidak kehilangan arah atau tujuan (loss purpose) untuk mewujudkan negara hukum yang demokratis. ${ }^{18}$

Daniel S. Lev mengingatkan bahwa untuk memahami sistem hukum di tengah-tengah transformasi politik harus diamati dari mulai bawah dan diperhatikan pula peran sosial politik apa yang diberikan orang kepadanya, karena lebih kuatnya konsentrasi energi politik, maka menjadi lebih beralasan bahwa otonomi hukum di Indonesia diintervensi oleh politik. ${ }^{19}$

Keikutsertaan Indonesia ke dalam organisasi perdagangan dunia (World Trade Organizations) adalah era baru intervensi politik ekonomi dunia terhadap arah kehidupan politik hukum di Indonesia. Karl Deutsh pernah mengemukakan relasi WTO terhadap kedaulatan hukum energi nasional masing-masing negara anggotanya. Deutsh mengatakan: "di dunia dewasa ini, negara...adalah sesuatu yang tidak bisa diabaikan namun juga tidak memadai. Negara adalah alat paling utama untuk

\footnotetext{
${ }_{17}$ Mohammad Mahfud MD., Perdebatan Hukum Tata Negara Pasca Amandemen Konstitusi, LP3ES, Jakarta, 2007, hlm. 48 - 49.

18 I Gusti Ayu Ketut Rachmi Handayani, "Formulasi Legislative Drafting yang Ideal dalam Rangka Mewujudkan Negara Hukum yang Demokratis dan Menuju Nilai-nilai Lingkungan" Jurnal Hukum Ius Quia Iustum, Volume 22, No. 3 Juli 2015, hlm. 385.

${ }^{19}$ Daniel S. Lev, Islamic Courts in Indonesia, University of California Press, Berkeley, 1972, hlm. 2.
} 
menjalankan sesuatu dan menghadapi banyak problem. Tetapi negara tak memadai untuk mengatasi bertambahnya problem kehidupan dan kematian warga negaranya."20

Sejalan dengan Deutsh di atas, Gianfrancco Poggi mengemukakan bahwa pengaruh kapitalisme dan liberalisme dalam sebuah proses politik hukum sekarang ini cenderung mendominasi, selengkapnya Poggi mengatakan bahwa :“...capitalism is system of power. It entails the self perpetuating dominance of the capital owning class over...". ${ }^{21}$

Berdasarkan pemikiran Karl Deutsh dan Gianfrancco Poggi di atas, sebaiknya politik hukum di masa depan khususnya dalam pengelolaan SDE Indonesia meliputi substansi, struktur dan kulturnya, baik secara filosofis, yuridis, maupun sosiologis harus tetap dilandasi oleh nilai-nilai Pancasila (grundnorms dan filosofische grondslag) dengan basis lingkungan hidup, demi terwujudnya cita-cita negara untuk melindungi segenap bangsa Indonesia dan seluruh tanah air Indonesia yang dikelola secara arif bijaksana untuk sebesar-besarnya kemakmuran rakyat. Meskipun sekarang ini gelombang global ekonomi sangat sulit dihindari, seperti dikatakan oleh George Soros, yaitu bahwa " ...we have a global economy without a global society..."22 dan selanjutnya Thurow mengatakan bahwa,"...the world is going to have a global economy without a global government..."23.

\section{Penutup}

Berdasarkan uraian pembahasan di atas, dapat ditarik kesimpulan sebagai benang merah dari ketiga pokok permasalahan tersebut. Pertama, politik hukum terkait pengelolaan SDE yang ada sekarang ini cenderung mengutamakan kepentingan ekonomi sesaat serta relatif lebih banyak diwarnai oleh kepentingankepentingan pasar liberalis dan kapitalisasi SDE dibandingkan nilai pengelolaan SDE yang berdasarkan nilai falsafah Pancasila dan berbasis lingkungan hidup.

${ }^{20}$ Wayne Parson, Public Policy; An Introduction to the Theory and Practice of Policy Analysis, London UK, Edward Elgar Publishing, 2001, Ltd, alih bahasa oleh Tri Wibowo Budi Santoso, Public Policy; Pengantar Teori dan Praktek Analisis Kebijakan, Kencana Prenada Media Group, Jakarta, 2011, hlm.24-25.Baca juga dalam Edi As'Adi, Loc.Cit.

${ }^{21}$ Elli Ruslina, Dasar-Dasar Perekonomian Indonesia dalam Penyimpangan Mandat Konstitusi UUD Negara Tahun 1945, Jakarta, Total Media dan P3IH FH.Universitas Muhammadiyah Jakarta, 2013, hlm.171.

${ }^{22}$ George Soros, Open Society, Reforming Global Capitalism, Public Affairs, New York, 2006, Baca juga dalam Edi As'Adi, Loc.Cit., hlm.2

${ }^{23}$ Lester. C. Thurow, Creating Wealth; The New Ruler for Individual, Companies and Countries in a Knowledge Based Economy, Nicholas Brealy, London, 2000, hlm.8. 
Kedua, politik hukum pengelolaan SDE cenderung inkonstitusional, seperti terlihat di dalam fakta-fakta hukum berupa putusan Putusan Mahkamah Konstitusi RI No.83/PUU-XI/2013 tentang pembayaran ganti rugi terhadap korban bencana lumpur Sidoarjo; Putusan Mahkamah Konstitusi RI No. 001-021/PUU-I/2003 tentang uji materiil UU No. 20 Tahun 2002 tentang Ketenagalistrikan; Putusan Mahkamah Konstitusi RI No.002/PUU-I/2003 tentang uji material UU No.22 tahun 2001 tentang Minyak dan Gas Bumi, Putusan Mahkamah Konstitusi RI No.36/PUU-X/2012 tentang uji matriil UU No. 22 Tahun 2001 terhadap pembubaran BP Minyak dan Gas Bumi. Ketiga, politik hukum di masa depan khususnya dalam pengelolaan SDE Indonesia meliputi substansi, struktur dan kulturnya baik secara filosofis, yuridis, dan sosiologis harus tetap dilandasi oleh nilai-nilai Pancasila (grundnorms dan filosofische grondslag) dengan basis lingkungan hidup berdasarkan konsep demokrasi ekonomi Pancasila dalam mewujudkan sebesar-besarnya kemakmuran rakyat.

\section{Daftar Pustaka}

\section{Buku}

Arief, Barda Nawawi, "Kumpulan Hasil Seminar Hukum Nasional Ke I s/d VIII dan Konvensi Hukum Nasional 2008 tentang UUD 1945 sebagai Landasan Konstitusional Grand design Sistem dan Politik Hukum Nasional", Badan Penerbit Universitas Diponegoro Pustaka Magister, Cetakan Ketiga, Semarang, 2011.

As'Adi, Edi, Rekonstruksi Regulasi Energi Nasional Dalam Melindungi Hak Rakyat Atas Energi Berbasis Hukum Progresif; Studi Regulasi Harga Keekonomian Bahan Bakar Minyak Bersubsidi, Undip, Semarang, 2015.

Handayani, I Gusti Ayu Ketut Rachmi, Pengantar Hukum Lingkungan, Cakrabooks, Surakarta, 2014.

Lev, Daniel S., Islamic Courts in Indonesia, University of California Press, Berkeley, 1972.

Marzuki, Peter Mahmud, Penelitian Hukum, Prenada Media, Jakarta, 2006.

MD., Mohammad Mahfud, Perdebatan Hukum Tata Negara Pasca Amandemen Konstitusi, LP3ES, Jakarta, 2007.

Moleong, Lexy J., Metodologi Penelitian Kualitatif, PT Remaja Rosdakarya, Bandung, 2005.

Parsons, Wayne, Public Policy;An Introduction to the Theory and Practice of Policy Analysis, London UK, Edward Elgar Publishing, Ltd, alih bahasa oleh Tri 
Wibowo Budi Santoso, 2011, Public Policy; Pengantar Teori dan Praktek Analisis Kebijakan, Kencana Prenada Media Group, Jakarta, 2001.

Posner, Richard A., Economic Analysis of Law, Fifth.ed.Aspen Publishers, New York, 1998.

Ruslina, Elli, Dasar-Dasar Perekonomian Indonesia dalam Penyimpangan Mandat Konstitusi UUD Negara Tahun 1945, Total Media dan P3IH FH. Universitas Muhammadiyah Jakarta, Jakarta, 2013.

Samekto, FX. Adji, Keterkaitan Kapitalisme Dengan Konsep Pembangunan Berkelanjutan dan Implementasi Konvensi Keanekaragaman Hayati dalam Kajian Studi Hukum Kritis (Critical Legal Studies), Undip, Semarang, 2003.

Sekjen dan Kepaniteraan Mahkamah Konstitusi RI, Himpunan Putusan Mahkamah Konstitusi Republik Indonesia, Mahkamah Konstitusi RI, Jakarta, 2004.

Soros, George, Open Society, Reforming Global Capitalism, Public Affairs, New York, 2006.

Syarif, Amiroedin, Perundang-undangan Dasar, Jenis dan Tekhnik Membuatnya, Bina Aksara, Jakarta, 1987.

Thurow, Lester. C., Creating Wealth; The New Ruler for Individual, Companies and Countries in a Knowledge Based Economy, Nicholas Brealy, London, 2000.

Wilardjo, Liek, Menerawang di Kala Senggang, Fakultas Teknik Elektro dan Program Pascasarjana Studi Pembangunan Universitas Kristen Satya Wacana, Salatiga, 2009.

\section{Artikel Jurnal}

Handayani, I Gusti Ayu Ketut Rachmi, “Formulasi Legislative Drafting yang Ideal dalam Rangka Mewujudkan Negara Hukum yang Demokratis dan Menuju Nilai-nilai Lingkungan" Jurnal Hukum Ius Quia Iustum, Volume 22, No. 3 Juli 2015.

, "Penguatan Fungsi Lingkungan Hidup Melalui Penegakan Hukum Lingkungan Sesuai Undang-Undang Nomor 32 Tahun 2009 tentang Perlindungan dan Pengelolaan Lingkungan Hidup", Yustisia, Nomor 78 September-Desember 2009.

\section{Peraturan Perundang-undangan}

Undang-Undang Nomor 32 Tahun 2009 tentang Perlindungan dan Pengelolaan Lingkungan Hidup (Lembaran Negara Republik Indonesia Tahun 2009 Nomor 140, Tambahan Lembaran Negara Republik Indonesia Nomor 5059).

Undang-Undang 30 Tahun 2007 tentang Energi (Lembaran Negara Republik Indonesia Tahun 2007 Nomor 96, Tambahan Lembaran Negara Republik Indonesia Nomor 4746). 


\section{Internet}

https://id.wikipedia.org.," Banjir Lumpur Panas Sidoarjo", diakses tanggal 14 Juli 2016.

https:/ /m.tempo.co/read/news/2015/11/30/206723341/jokowi-diminta-bicaraenergi-bersih-di-cop-ke-21, diakses tanggal 14 Juli 2016 